https://doi.org/10.15407/frg2020.06.463

UDC 581.192

\title{
LECTIN ACTIVITY OF SOYBEAN SEEDS
}

\section{O.V. KYRYCHENKO}

Institute of Plant Physiology and Genetics, National Academy of Sciences of Ukraine 31/17 Vasylkivska St., Kyiv, 03022, Ukraine

e-mail: azoleki@ukr.net

The lectin activity of soybean seeds of both the sowing seeds and the yield seeds received by the pretreatment of sowing seeds with the purified soybean lectin as well as the lectin-rhizobium compositions on the bases of the soybean lectin and nodule bacteria Bradyrhizobium japonicum 634b was studied. It has been demonstrated that the application of compositions with high lectin concentrations (50 and $500 \mu \mathrm{g} / \mathrm{ml}$ ) increased lectin activity of yield seeds, whereas a composition with a low lectin content $(5 \mu \mathrm{g} / \mathrm{ml})$ doesn't increase lectin activity of yield seeds as compared with the sowing material (parental seeds). Application of a purified soybean lectin in concentration $500 \mu \mathrm{g} / \mathrm{ml}$ for the pre-sowing treatment of soybean seeds essentially increased lectin activity of yield seeds. We suggest using of soybean seed lectin at the concentration of $5 \mu \mathrm{g} / \mathrm{ml}$ to modify the rhizobial inoculant for soybean in order to minimize the accumulation of proteins with lectin activity in soybean yield seeds.

Key words: soybean, lectin, compositions, real lectin activity, specific lectin activity.

Phytolectins are natural substances - products of plants metabolism [13]. Lectins are molecules with a wide range of biological activities [4-9]. They are glycoproteins or oligomeric proteins with one or more sugarbinding site(s) per subunit. Lectins bind reversibly with specific sugars [10]. Carbohydrate specificity is a fundamental characteristic of phytohemagglutinin molecules $[10,11]$. Lectins in the plant seeds compose by $10-15 \%$ of the whole protein contents [1, 12]. They are located mostly in the cotyledons, but are found also in the embryo axes [13]. Lectins perform a much of physiological functions in the seeds. They promote protein reserve, and participate in the immobilization of carbohydrate and protein substances, provide aggregation and globulins packing during the process of filling protein vacuoles and turning them into protein bodies, and participate in the regulation of protein catabolism, show enzymatic properties ( $\alpha$-galactosidase of bean seeds), and influence on the functional capacity of some seed enzymes as well [1, 12, 13].

In previous works, we showed that exogenous treatment of seeds by plant lectin (soybean seeds lectin, wheat germ agglutinin) and bacterial compositions including this protein is an effective way of increasing the plant productivity. Thus, the pre-sowing treatment of soybean seeds by

Citation: Kyrychenko O.V. Lectin activity of soybean seeds. Fiziol. rast. genet., 2020, 52, No. 6, pp. 463-468. https://doi.org/10.15407/frg2020.06.463 
purified lectin in concentration 500 and $5 \mu \mathrm{g} / \mathrm{ml}$ increased the seed productivity of plants by $12 \%$ under the field conditions [14] and lectin-bacterial compositions with 500 and $5 \mu \mathrm{g} / \mathrm{ml}$ of soybean lectin led to increase of above mention index by 10 and $8 \%$ respectively as compared with the variant of the inoculation of seeds only by Bradyrhizobium japonicum 634b under the greenhouse and field conditions [7]. At the same time it was marked the increasing level of the endogenous lectin activity in the leaves of soybean plants [15].

Besides, a toxic effect of the plant lectins is known. Thus, the separate class of toxic lectins exists - ribosomal-inactivating proteins of type 2 (2RIPs), which has a high toxicity for eukaryotes by means of capability to damage ribosome, and as a result of this, to repress the elongation of protein synthesis and cause the cells destruction [16]. Soybean lectin doesn't belong to a class of proteins 2RIPs and it is low toxic for men and animals. However, the repression of iron adsorption in the intestine of rats by the effect of soybean lectin is known [17], and the negative effect of this lectin in the dose more than $2 \mathrm{mg} / \mathrm{g}$ of food was marked, which became apparent in considerable repression of the growth of rats mass, in appearance of nitrogen in urine, decrease of the insulin level in blood plasma. Soybean lectin in doses of $0.1-1.4 \mathrm{mg} / \mathrm{g}$ of food has not a negative effect when using by rats, and the nitrogen balance in animals [18].

Paying attention to said above, it is necessary to research the endogenous lectin activity not only during the plant vegetation, but also in soybean yield seeds under using the composition with lectin for the treatment of sowing seeds to solve the problem of the possible accumulation of the lectin-like proteins in the following plant generation as compared with the sowing seeds.

The aim of this investigation was to determine and compare the lectin activity of soybean seeds, which was used as the sowing material and the yield seeds under the effect of the soybean lectin and lectin-bacterial compositions on sowing seeds.

\section{Materials and methods}

Soybean plants (Glycine $\max$ L. Merr) cultivar Maryana (bred by the Institute of Plant Physiology and Genetics National Academy of Sciences of Ukraine - IPPG NAS of Ukraine, Kyiv), soybean seeds lectin («Lectinotest», Lviv, Ukraine) and lectin-bacterial compositions based on the soybean seeds lectin and the nitrogen-fixing nodule bacteria Bradyrhizobium japonicum 634b (collection of microorganisms at the Department of the Symbiotic Nitrogen Fixation of IPPG NAS of Ukraine) were used in these investigations. The acting concentration of lectin in lectin-bacterial compositions was 5,50 and $500 \mu \mathrm{g} / \mathrm{ml}$, the bacterial suspension contained $10^{7}$ cells $/ \mathrm{ml} \mathrm{[7].} \mathrm{The} \mathrm{purified} \mathrm{soybean} \mathrm{seeds} \mathrm{lectin} \mathrm{of}$ concentration $500 \mu \mathrm{g} / \mathrm{ml}$ was used also [14].

The greenhouse experiment was performed in 10-kg Wagner pots (5 per the variant) filled with a sand, and the Gelrigel nutrient medium ( 0.25 of mineral nitrogen of norm was added). Prior to sowing the seeds 
were treated for $1 \mathrm{~h}$ either by the compositions of lectin with bacteria $(1: 1)$, or inoculated by B. japonicum $634 \mathrm{~b}$ (bacterial control), or treated by water (absolute control), or purified lectin. The soybean seeds yield was harvested at the stage of the complete seeds ripeness.

Proteins were extracted from soybean seeds by $76 \%$ ethanol [12], and their contents estimated in the samples by Whitaker and Einar method [19]. The hemagglutinating assays [12] were performed using $2 \%$ suspension of $0(\mathrm{I}, \mathrm{Rh}+)$ group of human red blood cells. The value, being turned to the titre of agglutination, was taken as a real lectin activity (RLA), which was expressed as the agglutination units (UA) in $50 \mu \mathrm{l} \mathrm{solu-}$ tion (UA $\left.(50 \mu \mathrm{l})^{-1}\right)$. The specific lectin activity (SLA) that as the agglutination titre, is a relative index of the quantitative lectin contents in the samples, was calculated as the agglutination activity of $1 \mathrm{mg}$ protein and was expressed as the units of agglutination of $1 \mathrm{mg}$ protein $\left(\mathrm{UA} \mathrm{mg}^{-1}\right.$ ).

The statistical analysis of the results was performed with the computer program Statgraphics Software Statistical Package 5.0 and the results are presented in the paper as mean \pm standard error of mean (SEM).

\section{Results and discussion}

Determination of the lectin activity in soybean seeds, which were used as a sowing material as well as yield seeds of all experimental variants showed quite high hemagglutination activity (RLA 16-64 UA $(50 \mu \mathrm{l})^{-1}$ and SLA 197.3-1184.7 UA $\mathrm{mg}^{-1}$ of protein), which prove the presence of the lectin-like proteins in soybean seeds (Table).

Soybean sowing seeds were characterized by the indices of RLA and SLA respectively $32 \mathrm{UA}(50 \mu \mathrm{l})^{-1}$ and $497.1 \mathrm{UA} \mathrm{mg}^{-1}$ of protein. The changes in the lectin activity of soybean seeds depended on the pretreatment of sowing seeds by the compositions or lectin. Thus, in the soybean yield seeds of the control variant (treatment of seeds by water) both real and specific lectin activity was lower respectively in 2.0- and 2.5-fold compared with parental sowing seeds. The same accordance was also determined for the yield seeds lectin activity in the treatment with the inocula-

The lectin activity of soybean seeds

\begin{tabular}{lcccc}
\hline \multirow{2}{*}{ Treatment } & $\begin{array}{c}\text { Real lectin } \\
\text { activity (RLA), } \\
\text { UA (50 } \mu)^{-1}\end{array}$ & \multicolumn{2}{c}{ Specific lectin activity (SLA) } \\
\cline { 3 - 4 } & 16 & UA mg ${ }^{-1}$ of protein & $\%$ \\
\hline Water (absolute control) & 16 & $197.3 \pm 5.7$ & 25 \\
Bradyrhizobium japonicum $634 \mathrm{~b}$ & & $237.8 \pm 4.3$ & 48 \\
(bacterial control) & 64 & & \\
B. japonicum $634 \mathrm{~b}+$ lectin $500 \mu \mathrm{g} / \mathrm{ml}$ & 64 & $983.1 \pm 0.1$ & 197 \\
B. japonicum $634 \mathrm{~b}+$ lectin $50 \mu \mathrm{g} / \mathrm{ml}$ & 32 & $943.4 \pm 10.6$ & 189 \\
B. japonicum $634 \mathrm{~b}+$ lectin $5 \mu \mathrm{g} / \mathrm{ml}$ & 64 & $474.1 \pm 1.4$ & 95 \\
Purified soybean seeds lectin $500 \mu \mathrm{g} / \mathrm{ml}$ & 32 & $1184.7 \pm 161.7$ & 238 \\
Sowing seeds & & $498.1 \pm 3.5$ & 100 \\
\hline
\end{tabular}

Note. UA - unit of agglutination; $\%$ - of the sowing seeds. 
tion of seeds by B. japonicum: values of the real and specific lectin activity were lower in 2.0- and 2.1-fold compared with the parental seeds. However, the SLA in the treatment with the inoculation of seeds was higher in 1.8-fold compared with absolute control value. This fact testifies that the pre-sowing soybean seeds inoculation by the nodule bacteria led to increase of the lectin activity in yield seeds.

Pre-sowing seeds treatment by lectin-rhizobium compositions with the agglutinin in concentrations 5,50 and $500 \mu \mathrm{g} / \mathrm{ml}$ as well as by the purified soybean lectin $(500 \mu \mathrm{g} / \mathrm{ml})$ caused the changes of lectin activity in yield seeds. The RLA values in the treatments of sowing seeds by the compositions with 500 and $50 \mu \mathrm{g} / \mathrm{ml}$ of lectin increased the RLA index in 2.0 times compared with parental seeds, in 4.0 times compared with absolute and bacterial control indices. The SLA of seeds in this treatments was higher in 5.0- and 4.0-fold compared with absolute and bacterial control values respectively.

The yield soybean seeds in the treatment with the composition containing $5 \mu \mathrm{g} / \mathrm{ml}$ of lectin was characterized by the RLA 32 UA $(50 \mu \mathrm{l})^{-1}$ and was equal to the RLA value in the paternal sowing seeds, while this index was higher by 2.0 -fold compared with both controls. The yield seeds SLA in this treatment was the same as the SLA of the parental seeds and it was higher by 3.6 times compared to the control treatments. In the yield seeds in the treatment with the composition containing $5 \mu \mathrm{g} / \mathrm{ml}$ of lectin, both the real and specific lectin activities were lower by 2.0 times compared with the seeds of the treatment with the compositions containing the lectin in concentrations 500 and $50 \mu \mathrm{g} / \mathrm{ml}$.

The obtained results demonstrate that treatment of seeds by exogenous lectin and the incubation with B. japonicum may stimulate the metabolic processes in both a bacterial cells and plant. Lectin as a part of the compositions combined with the bacterial cells changes their metabolism and symbiotic properties $[6,7,20,21]$, whereas lectin which has not connected with bacteria, directly effect on the development and physiological status of plants [14]. The increase of the endogenous lectin activity level in the leaves of soybean plants can be one of the displays of this process [15].

Such effect becomes especially evident during the analysis of soybean yield seeds lectin activity in the treatment of sowing seeds with purified lectin (see Table). The yield seeds SLA in this treatment exceeded significantly all the other treatments and was characterized by the maximum index. It value were 6.0 and 5.0 times higher than the absolute and bacterial controls, and 1.2, 1.3 and 2.5 times than the indices in the treatments with the lectin-bacterial compositions containing 500,50 and $5 \mu \mathrm{g} / \mathrm{ml}$ of lectin respectively, and 2.4 times higher than the lectin activity of the parental sowing seeds. It is evident that activation of the endogenous lectin synthesis in a plant takes place and the hemagglutination activity in the yield seeds increased significantly under the application of purified plant lectin and it compositions with bacteria.

Thus, the obtained results demonstrated that using of the purified lectin and lectin-containing compositions with high protein concentrations for the pre-sowing seeds treatment increased the lectin level in the yield seeds. The composition with the low lectin content doesn't increase the 
lectin activity in soybean yield seeds compared with the parental sowing seeds. We suggest using of soybean seed lectin at the concentration of $5 \mu \mathrm{g} / \mathrm{ml}$ to modify the rhizobial inoculant for soybean in order to minimize the accumulation of proteins with lectin activity in soybean yield seeds.

\section{REFERENCES}

1. Rudiger, H. \& Gabius, H.-J. (2001). Plant lectins: occurrence, biochemistry, functions and applications. Glycoconjugate J., 18, No. 8, pp. 589-613. https://doi.org/10.1023/ A:1020687518999

2. Van Damme, E.J.M., Lannoo, N. \& Peumans, W.J. (2008). Plant Lectins. Adv. Botanical Res., 48. pp. 107-209. https://doi.org/10.1016/S0065-2296(08)00403-5

3. Nikitina, V.E., Loshchinina, E.A. \& Vetchinkova, E.P. (2017). Lectins from mycelia of basidiomycetes. Int. J. Mol. Sci., 18, No. 7, pp. 1334-1350. https://doi.org/10.3390/ ijms18071334

4. Singh, K., Kaur, M., Rup, P.J. \& Singh, J. (2006). Exploration for anti-insect properties of lectin from seeds of soybean (Glicine max) using Bactrocera cucurbitae as a model. Phytoparasitica, 34, No. 5, pp. 463-473. https://doi.org/10.1007/BF02981200

5. Jiang, S., Ma, Z. \& Ramachandran, S. (2010). Evolutionary history and stress regulation of the lectin superfamily in higher plants. BMC Evol Biol., 10, No 1, pp. 79-103. https://doi.org/10.1186/1471-2148-10-79

6. Alenkina, S.A., Bogatyrev, V.A., Matora, L.Y., Sokolova, M.K., Chernyshova, M.P., Trurneva, K.A. \& Nikitina, V.E. (2014). Signal effects of the lectin from the associative nitrogen-fixing bacterium Azospirillum brasilense $\mathrm{Sp} 7$ in bacterial-plant root interactions. Plant Soil. No. 381, pp. 337-349. https://doi.org/10.1007/s11104-014-2125-6

7. Kyrychenko, O.V. (2014). Phytolectins and diazotrophs are the polyfunctional components of the complex biological compositions. Biotechnol Acta. 7, No 1, pp. 40-53 [in Ukrainian]. https://doi.org/10.15407/biotech7.01.040

8. Pavlovskaya, N.E. \& Gagarina, I.N. (2017). The physiological properties of plant lectins as a prerequisite for their application in biotechnology. Khimiya rastitelnogo syriya. No. 1, pp. 21-35 [in Russian].

9. Hendrickson O.D. \& Zherdev, A.V. (2018). Analytical application of lectins. Critical Rev in Analytical Chemistry, 48, No. 4, pp. 279-292. https://doi.org/10.1080/ 10408347.2017.1422965

10. Sharon, N. (2007). Lectins: carbohydrate-specific reagents and biological recognition molecules. J. Biol. Chem., 282, No. 5, pp. 2753-2764. https://doi.org/10.1074/ JBC.X600004200

11. Gabius, H.J. (2018). The sugar code: why glycans are so important. Bio Systems. 2018. 164, pp. 102-111. https://doi.org/10.1016/j.biosystems.2017.07.003

12. Antonyuk, V.O. (2005). Lectins and their raw material sources. PP «Kvart»: Lviv [in Ukrainian].

13. Aoyama, H., Cavagis, A.D.M., Taga, E.M. \& Ferreira, C.V. (2001). Endogenous lectin as a possible regulator of the hydrolysis of physiological substrates by soybean seed acid phosphatase. Phytochemistry, 58, No. 2, pp. 221-225. https://doi.org/10.106/s00319422(01)00190-x

14. Kyrychenko, O.V. (2008). Practice of soybean and wheat lectins use for the plant growing. Problems of Biogeochem. Geochemical Ecology, 1, pp. 99-105.

15. Kyrychenko, O.V. (2011). Changes in endogenous lectin activity of soybean plants under seeds treatment with exogenous lectin. Fyzyolohyia i byokhymyia kult. rasteniy, 43, No. 6, pp. 520-526 [in Ukrainian].

16. Hartley, M.R. \& Lord, J.M. (2004). Cytotoxic ribosome-inactivating lectins from plants. Biochem. Biophys. Acta., 1707, No. 1-2, pp. 1-14. https://doi.org/10.1016/j.bbapap.2004.06.004

17. Li, Z., Li, D. \& Qiao, S. (2003). Effect of soybean agglutinin on nitrogen metabolism and on characteristics of intestinal tissues and pancreas in rats. Arch. Tierernahr., 57, No. 5, pp. 369-380. https://doi.org/10.1080/00039420310001607725 
18. Hisayasu, S., Orimo, H., Migita, S., Ikeda, Y., Satoh, K., Shinjo, S., Hirai, Y. \& Toshino, Y. (1992). Soybean protein isolate and soybean lectin inhibit iron absorption in rats. J. Nutr., 122, No. 5, pp. 1190-1196. https://doi.org/10.1093/jn/122.5.1190

19. Whitaker, J.R. \& Einar, G. (1980). An absolute method for protein determination based on difference in absorbance at 235 and $280 \mathrm{~nm}$. Anal. Biochem., 109, No. 1, pp. 156-159. https://doi.org/10.1016/0003-2697(80)90024-x

20. Lodeiro, A.R., Lopez-Garcia, S.L., Vazquer, T.E.E. \& Favelukes, G. (2000). Stimulation of adhesiveness, infectivity and competitiveness for nodulation of Bradyrhizobium japonicum by its pretreatment with soybean seed lectin. FEMS Microbiol. Let., 188, No. 1, pp. 177-184. https://doi.org/10.1111/j.1574-6968.2000.tb09190.x

21. Kandelinskaya, O.L., Grischenko, E.R., Ripinskaya, K.Ju., Aleschenkova, Z.M., Kartizhova, L.E., Kuptsov, V.N. \& Kuptsov, N.S. (2015). Role of lectins in regulation of legume-Rhizobium symbiosis efficiency in lupin. Botanika (issledovaniya). Sb. Nauch. Tr.: In-t Experimentalnoy Botaniki of the National Academy of Scienses of Belarusi, 44, pp. 283-290 [in Russian].

Received 04.11.2020

\section{ЛЕКТИНОВА АКТИВНІСТЬ НАСІННЯ СОЇ}

\section{О.В. Кириченко}

Їнститут фізіології рослин і генетики Національної академії наук України 03022 Київ, вул. Васильківська, 31/17, Україна

e-mail: azoleki@ukr.net

Досліджено лектинову активність насіння сої як посівного, так і насіння урожаю, отриманого за передпосівної обробки посівного насіння очищеним лектином сої та композиціями на основі лектину сої й бульбочкових бактерій Bradyrhizobium japonicum 634б. Показано, що застосування композицій, які містили високі концентрації лектину сої (500 и 50 мкг/мл), привело до збільшення рівня лектинової активності у насінні урожаю, тоді як композиція з низькою концентрацією лектину (5 мкг/мл) не підвищувала лектинову активність насіння урожаю порівняно до посівного насіння. Використання очищеного лектину сої у концентрації 500 мкг/мл для передпосівної обробки насіння спричиняло істотне зростання лектинової активності в насінні урожаю. Пропонуємо застосовувати для модифікації бактеріального інокулянту під сою лектин насіння сої у концентрації 5 мкг/мл з метою мінімалізації накопичення протеїнів із лектиновою активністю в насінні урожаю сої.

Ключові слова: соя, лектин, композиції, фактична лектинова активність, питома лектинова активність. 